\title{
Characterization of Clay of the Benin Used in Ruminale Feeding. Complete Determination of the Smectites Contained in These Clays
}

\author{
Etienne Sagbo ${ }^{*}$, Marielle Agbahoungbata ${ }^{1}$, Wilfried Kangbode1, Arthur Cakpo', \\ Jacques Kinlehoume ${ }^{1}$, Jean-Baptise Mensah'2, Yves Noack ${ }^{3}$ \\ ${ }^{1}$ Laboratoire de Chimie Inorganique et de I'Environnement (LaCIE), Faculté des Sciences et Techniques (FAST), \\ Université d'Abomey-Calavi, Cotonou, Bénin \\ ${ }^{2}$ Laboratoire de Chimie Théorique et de Spectroscopie Moléculaire (LACTHESMO), Faculté des Sciences et \\ Techniques (FAST), Université d'Abomey-Calavi, Cotonou, Bénin \\ ${ }^{3}$ Centre Européen de Recherche et d'Enseignement en Géosciences de L'Environnement (CEREGE), Université \\ d'Aix Marseille, Aix en Provence, France \\ Email: *esagbo@yahoo.fr
}

Received 31 August 2015; accepted 27 November 2015; published 30 November 2015

Copyright (C) 2015 by authors and Scientific Research Publishing Inc.

This work is licensed under the Creative Commons Attribution International License (CC BY).

http://creativecommons.org/licenses/by/4.0/

\section{(c) (i) Open Access}

\begin{abstract}
In this work, by the use of several physico-chemical complementary methods for the characterization of soil (diffraction of $x$-rays, chemical analysis, density, cationic exchange capacity, specific surfaces, mössbauer, granulometry, etc.), the smectite of the three clayey localities of Benin (GbédjiKotovi, Massi-Sèhouè and Zogbodomey) was notably studied. Thus, these three sites contain principally smectite, kaolinite and quartz in variable proportion. This smectite is a beidellite. Its chemical formula is proposed. The specific surfaces and the cationic exchange capacity of the samples are determined. For these samples, the fraction lower than $2 \mu \mathrm{m}$ is practically beidellitic for Gbédji-Kotovi and Massi-Sèhouè (more than $82 \%$ of beidellite) and practically kaolinitic (70\% of kaolinite) for Zogbodomey. So, used as additive food to ruminant, the clay of Gbédji-Kotovi and Massi-Sèhouè will induce an enteric reduction of methane more than clay of Zogbodomey.
\end{abstract}

\section{Keywords}

Clay, Characterization, Beidellite, Formula, Bénin

\section{Introduction}

In order to optimize digestion of ruminants and reduce the emission of the enteric methane which constitutes a *Corresponding author.

How to cite this paper: Sagbo, E., Agbahoungbata, M., Kangbode, W., Cakpo, A., Kinlehoume, J., Mensah, J.-B. and Noack, Y. (2015) Characterization of Clay of the Benin Used in Ruminale Feeding. Complete Determination of the Smectites Contained in These Clays. Journal of Environmental Protection, 6, 1322-1336. http://dx.doi.org/10.4236/jep.2015.611115 
loss of energy for the animal and an economic loss for the cattle breeders [1], it is incorporated in Bénin clay in ruminale feeding. Indeed, clay is well known for its specific surface, its capacity of cationic exchange and its richness in necessary cations for ruminale feeding [2].

The clayey samples which are used are taken in the south of the Bénin. The characteristics of these clays previously were the object of some rare chemical analyses and studies with x-rays [3]. Thereafter, it was given some characteristics of total fractions of these clays [4]. Then, the good knowledge of the characteristics (compositions and properties) of the argillaceous fractions used, and especially of the smectites contained in these samples will make possible to improve the hoped outputs. It is accordingly that, this study is accomplished by combining several methods (diffraction of x-rays, the chemical analysis, the density, the cationic capacity of exchange, the exchangeable bases, specific surfaces granulometry and mössbauer, etc.). This work will make possible to select clays which are likely to involve a clear reduction of enteric methane and to fatten animals.

\section{Materials and Methods}

\subsection{Materials}

Located in the south-west of the Benin between meridians $1^{\circ} 40^{\prime} \mathrm{E}$ and $2^{\circ} 45^{\prime} \mathrm{E}$ and parallels $6^{\circ} 15^{\prime} \mathrm{N}$ and $7^{\circ} 30^{\prime} \mathrm{N}$, the basin where the samples were took belongs to the basins of the Gulf of Guinea (Figure 1) The pluviometric annual average is there of $1200 \mathrm{~mm}$. Temperature varies around $29^{\circ} \mathrm{C}$ and the vegetation is presented in the form of arboreous savanna. On the geomorphological level, this basin includes two zones (Figure 2): A zone of 7 plateau limited by the valleys of the main rivers (Ouémé, Sô, Couffo and Mono) and the depression of Lama. They are the plateau of Aplahoué, of Abomey, of Zagnanado and of Kétou and those of Comé, of Allada and of Saketé and a zone of low plain constituting a margino-coastal domain occupied by marshy depressions, lagoons (lagoon of Porto Novo, coastal lagoon), sand cords and lakes (lake Ahémé, lake Nokoué). On geological level, this basin is of cretaceous age to présent. Il contain gritty, sandy, argillaceous and calcareous formations [5] [6].

The studied materials come from deposits of Gbedji-Kotovi (GK), of Massi-Sèhouè (MS), and of Zogbodomey (ZY).These sites are represented on the Figure 2. The 1st site (GK) prospected is between longitude $2^{\circ} 00^{\prime} \mathrm{E}$ and $2^{\circ} 02 \mathrm{E}$, and between latitude $6^{\circ} 40^{\prime} \mathrm{N}$ and $6^{\circ} 42^{\prime} \mathrm{N}$. The relief is there slightly undulating there .The studied deposit (during dry season) is in the bed of the river Couffo. Ten wells of $1 \mathrm{~m}$ of diameter and of $5 \mathrm{~m}$ of maximum depth are dug there in the stitch of $100 \mathrm{~m}$ (Table 1). Globally the clay, of black grey colour with by place of tasks rusts, is very plastic. The 2 nd site (MS) is between $2^{\circ} 13^{\prime} \mathrm{E}$ and $2^{\circ} 16^{\prime} \mathrm{E}$, between $6^{\circ} 57^{\prime} \mathrm{N}$ and $6^{\circ} 59^{\prime} \mathrm{N}$ in the depression of Lama. The relief, here, is generally flat. 10 wells in the stitch of $100 \mathrm{~m}$ and of maximum depth $5 \mathrm{~m}$ mostly and sometimes $7 \mathrm{~m}$ are explored here (Table 1). The clay is plastic and in general of beige gray color. When to 3rd site (ZY) it also presents, with a light slope towards the east, a flat and monotonous relief between $2^{\circ} 06^{\prime} \mathrm{E}$ and $2^{\circ} 08^{\prime} \mathrm{E}$ and between $7^{\circ} 04^{\prime} \mathrm{N}$ and $7^{\circ} 06^{\prime} \mathrm{N}$. This zone is to the bottom of the plate of Abomey; 6 wells in bulk, of maximum depth $7 \mathrm{~m}$ are exploited there (Table 1 ).

In general, clay appears only after one lateritic layer of 2 to $3 \mathrm{~m}$. It is initially white with red passages (zone of transition), then white with yellow passages and of the red tasks. The precise geographical co-ordinates of wells were raised with the aid of a positioning system by portable satellite of type G.P.S (Global Positioning System) and regrouped in Table 1.

According to later results (KANGBODE), the major crystalline phases contained in all the total samples are the following minerals: kaolinite (K): $\mathrm{Al}_{2} \mathrm{Si}_{2} \mathrm{O}_{5}(\mathrm{OH})_{4}$ (7.14 $\AA$; $3.56 \AA$ ), quartz (Q): $1.81 \AA$; $4.26 \AA$.) [7], smectite (S): (Ca, $\mathrm{Mg})(\mathrm{Al}, \mathrm{Fe})_{2}(\mathrm{Si}, \mathrm{Al}) \mathrm{O}_{10}(\mathrm{OH})_{2}(14-15 \AA)$ [8] and like phase trace the anatase $(\mathrm{A}): \mathrm{TiO}_{2}(3.52 \AA ; 1.89$ $\AA$ ). There are also feldspar traces $(\mathrm{Na}, \mathrm{K}, \mathrm{Ca})(\mathrm{Al}, \mathrm{Fe}, \mathrm{Si})_{4} \mathrm{O}_{8}(3.18$ - $3.33 \AA$; 4.02 - $4.25 \AA$ ) for the samples of Gbedji-Kotovi and particularly for $\mathrm{GSO}_{1 / 2}$ and goethite $(\mathrm{G}) \alpha$-FeOOH (4.18 $\AA$; $2.49 \AA$ ) for the samples of Zogbodomey.

The samples coming from the same site present the same ores showing of this fact the homogeneity of each site. What enabled us to choose there after a representative sample by locality for certain analyses with GNE1 $(\mathrm{G})$, its fraction fine or normal GNEIN (GN) and saturated with glycol GNEIG for Gbedji-Kotovi (GK), and with respectively MNO1 (M), MNOIN (MN) and MNOIG for Sehoue-Massi (MS) and ZTII2 (Z), ZTI2N (ZN) and ZTI2G for Zogbodomey (ZY).

\subsection{Methods}

The argillaceous fraction lower than $2 \mu \mathrm{m}$ of diameter is obtained by purification and sedimentation. This fine 


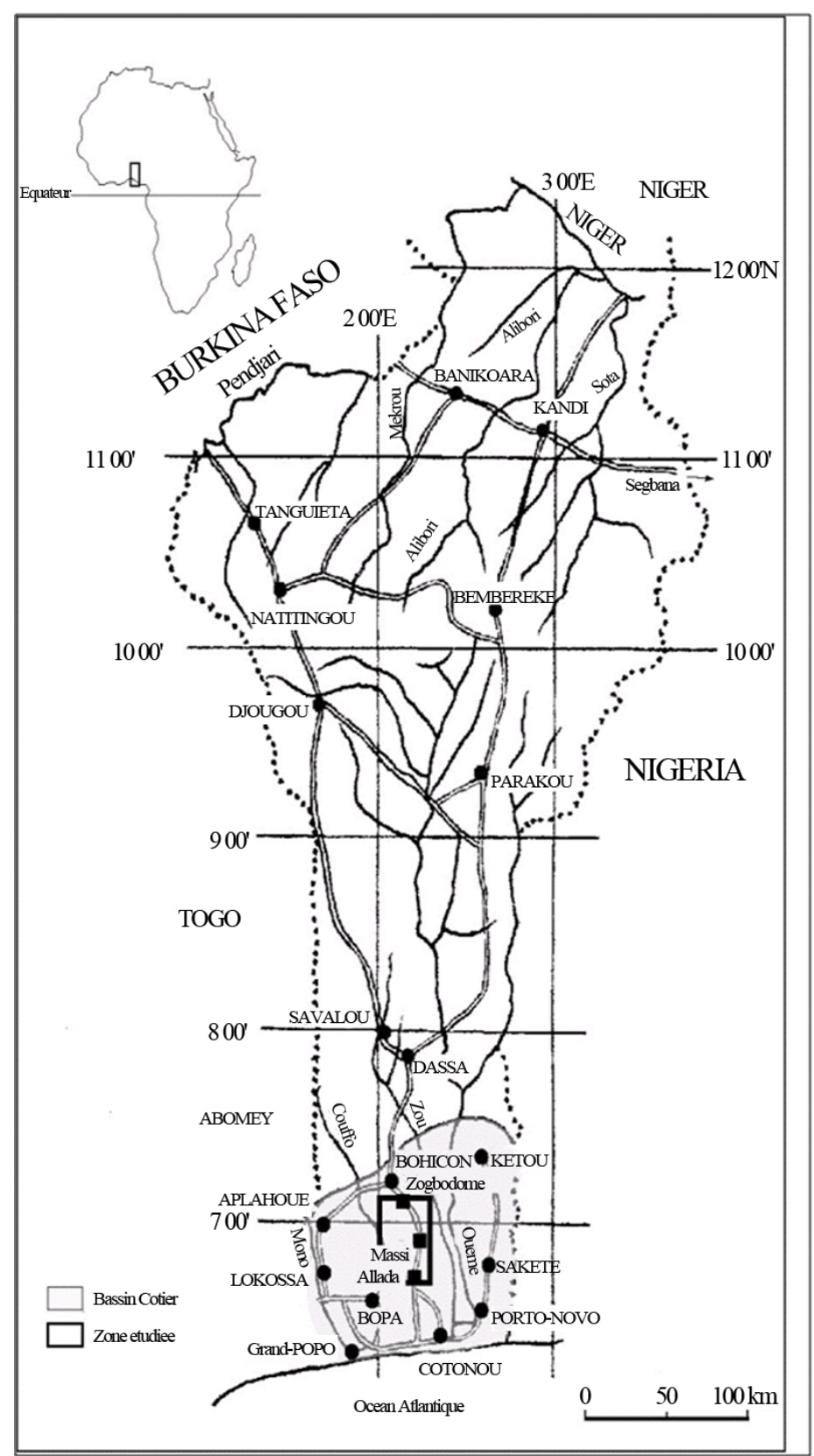

Figure 1. Card of géographical situation of Benin (IHETA et al., 1983).

fraction, dried and finely crushed allowed to prepare oriented pastes on natural trial and having undergone specific treatments (Ethylene glycol, Hydrazine, heating during 4 hours at $490^{\circ} \mathrm{C}$ ). These oriented pastes were subjected to diffraction $\mathrm{x}$-rays on powder. The diffractograms were recorded a Philips diffractometer equipped with a generator PW 1800 with graphite monochromator, using the radiation of cobalt and functioning under $40 \mathrm{Kv}, 40$ mA. They were acquired by data APD and were treated by the software X' PERT \& IDENTIFY and X' PERT High Score Plus. The results obtained by DRX are supplemented by the elementary chemical analyses. It is about an atomic spectrophotometer of emission by coupling of inductive plasma (I.C P./AES) Jobin Yvon of the mark Ultima C V5 which makes it possible to proportion the chemical elements constitutive of argillaceous material. The granulometric analysis was carried out on the fine grounds of diameter D lower than $500 \mu \mathrm{m}$ using a laser particle-measurement instrument MALVERN of the type MATERSIZER. Specific surfaces were given from the analysis of the isotherm of adsorption of a gas by the solid by using the method of Brunauer, 


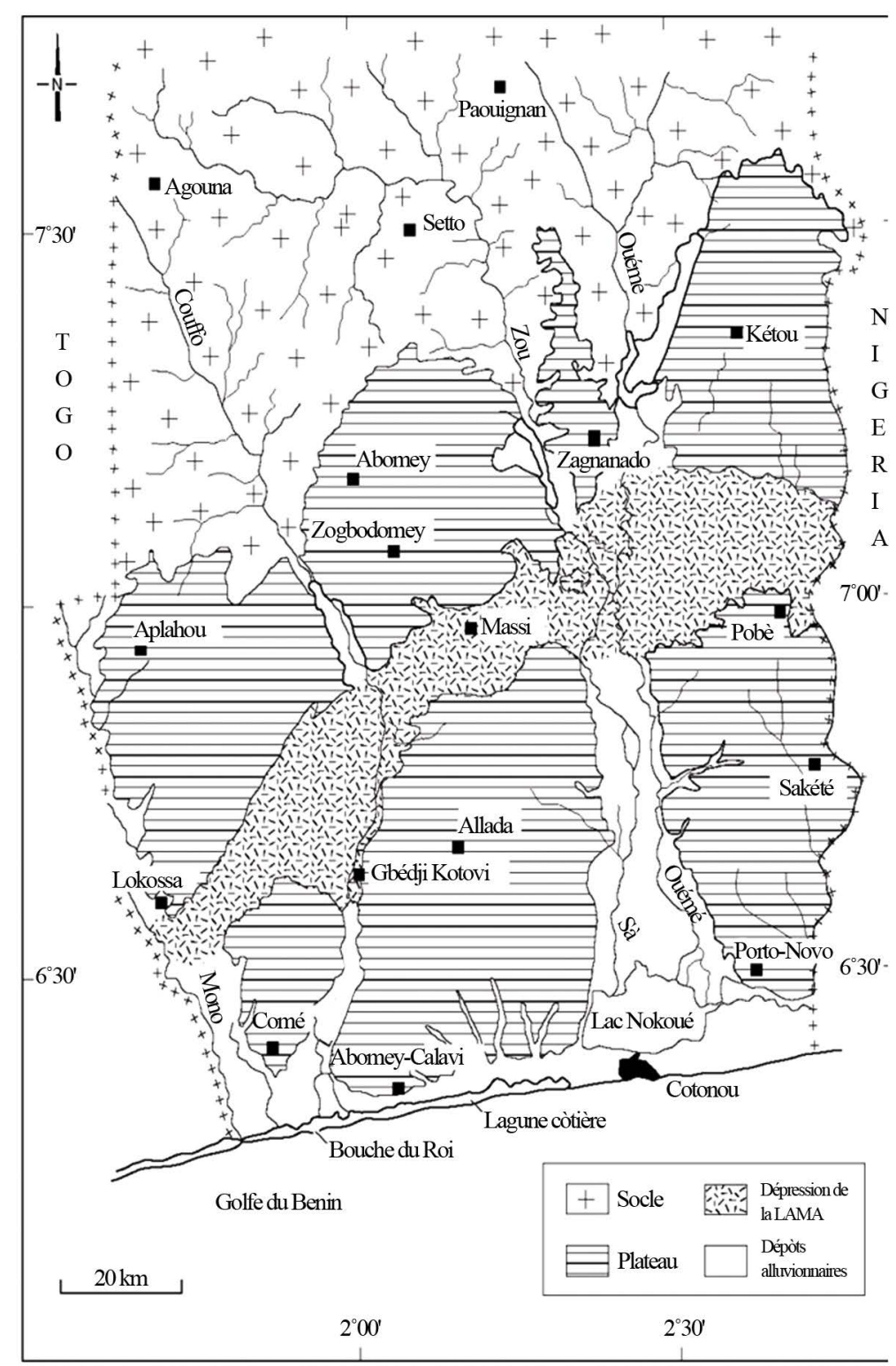

Figure 2. Geomorphological card of the coastal basin of the Benin (Slansky, 1962).

Emmett and Teller (B.E.T.). The measurement of the CEC by the method of Aubert [9], was done on the total rock. For the infrared spectroscopy, after a mixture (2\% in mass approximately) with of $\mathrm{KBr}$ (average IR) or polyethylene (remote IR), the samples, (fine fraction $<2 \mu \mathrm{m}$ ) are put in pastilles of diameter of $13 \mathrm{~mm}$ and of thickness of about $0.4 \mathrm{~mm}$. Measurements were carried out in the field of the average infra-red between 400 $\mathrm{cm}^{-1}$ and $4000 \mathrm{~cm}^{-1}$ using a spectrometer with Fourier transform of the type PERKIN ELMER (model 1760X), provided with a software of automatic processing data. In the remote infra-red (between $50 \mathrm{~cm}^{-1}$ and $400 \mathrm{~cm}^{-1}$ ), the spectra IR were recorded with a spectrometer BONEM D.A.8 with Fourier transform Moreover for Mössbauer our samples were analyzed in transmission using a standard Spectrometer EG \& G assembly equipped with a 57Co source (Rh). The rate of travel was gauged by reference to the sextuplet recorded starting from a pure sheet of Fe. The values of displacement are referred compared to the center of the spectrum, for a zero value of acceleration. The absorbing material was prepared with crushed clay $1.5 \mathrm{~g}$ approximately, inserted in a support surrounded by lead. The spectra, by using the Lorentzian, were calculated with the program ISO [10]. Isometric displacements are given compared to metal iron. The refinements were controlled by the test $\chi^{2}$. 
Table 1. Localization of the samples.

\begin{tabular}{|c|c|c|c|c|c|c|c|c|c|}
\hline \multicolumn{4}{|c|}{ Clays of Gbedji-Kotovi } & \multicolumn{3}{|c|}{ Clays of Zogbodomey } & \multicolumn{3}{|c|}{ Clays of Sehoue-Massi } \\
\hline Number of Wells & $\begin{array}{l}\text { Coordinates } \\
\text { by GPS }\end{array}$ & Samples & Depth (m) & $\begin{array}{l}\text { Coordinates } \\
\text { by GPS }\end{array}$ & Samples & Depth (m) & $\begin{array}{l}\text { Coordinates } \\
\text { by GPS }\end{array}$ & Samples & Depth (m) \\
\hline \multirow{2}{*}{1} & \multirow{2}{*}{ 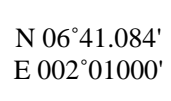 } & GNO1 & 0.2 & \multirow{2}{*}{$\begin{array}{l}\text { N } 07^{\circ} 04025^{\prime} \\
\text { E } 002^{\circ} 07326^{\prime}\end{array}$} & \multirow{2}{*}{$\mathrm{ZPO}$} & \multirow{2}{*}{3} & \multirow{2}{*}{$\begin{array}{l}\text { N } 06^{\circ} 57602^{\prime} \\
\text { E } 002^{\circ} 15249^{\prime}\end{array}$} & MNO1 & 0.05 \\
\hline & & GNO2 & 4.5 & & & & & MNO2 & 5 \\
\hline \multirow{2}{*}{2} & \multirow{2}{*}{$\begin{array}{l}\text { N } 06^{\circ} 41049^{\prime} \\
\text { E } 002^{\circ} 00965^{\prime}\end{array}$} & GO1 & 0.2 & \multirow{2}{*}{$\begin{array}{l}\text { N } 07^{\circ} 04051^{\prime} \\
\text { E } 002^{\circ} 06170^{\prime}\end{array}$} & ZPI1 & 2.95 & \multirow{2}{*}{$\begin{array}{l}\text { N } 06^{\circ} 57476^{\prime} \\
\text { E } 002^{\circ} 15198^{\prime}\end{array}$} & MO1 & 0.12 \\
\hline & & GO2 & 5 & & ZPI2 & 5 & & MO2 & 1.82 \\
\hline \multirow{2}{*}{3} & \multirow{2}{*}{ 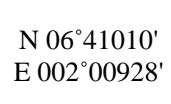 } & GSO1 & 0.5 & \multirow{2}{*}{$\begin{array}{l}\text { N 07 } 05022^{\prime} \\
\text { E } 002^{\circ} 06309^{\prime}\end{array}$} & ZPII1 & 2.95 & \multirow{2}{*}{$\begin{array}{l}\text { N } 06^{\circ} 57429^{\prime} \\
\text { E } 002^{\circ} 15232^{\prime}\end{array}$} & MSO1 & 0.15 \\
\hline & & GSO2 & 1.2 & & ZPII2 & 7 & & MSO2 & 5 \\
\hline \multirow{2}{*}{4} & \multirow{2}{*}{$\begin{array}{l}\text { N } 06^{\circ} 41084^{\prime} \\
\text { E } 002^{\circ} 01062^{\prime}\end{array}$} & GNN1 & 0.25 & \multirow{2}{*}{$\begin{array}{l}\text { N } 07^{\circ} 04148^{\prime} \\
\text { E } 002^{\circ} 07170^{\prime}\end{array}$} & ZPIII1 & 3 & \multirow{2}{*}{$\begin{array}{l}\text { N } 06^{\circ} 57325^{\prime} \\
\text { E } 002^{\circ} 15317^{\prime}\end{array}$} & MSSO1 & 0.05 \\
\hline & & GNN2 & 5 & & ZPIII2 & 7 & & MSSO2 & 2.6 \\
\hline \multirow{2}{*}{5} & \multirow{2}{*}{$\begin{array}{l}\text { N } 06^{\circ} 40985^{\prime} \\
\text { E } 002^{\circ} 00995^{\prime}\end{array}$} & GN1 & 0.20 & \multirow{2}{*}{$\begin{array}{l}\text { N } 07^{\circ} 04821^{\prime} \\
\text { E } 002^{\circ} 06176^{\prime}\end{array}$} & ZTI1 & 2.95 & \multirow{2}{*}{ 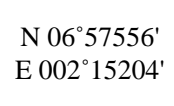 } & MN1 & 0.12 \\
\hline & & GN2 & 5 & & ZTI2 & 6.2 & & MN2 & 5 \\
\hline \multirow{2}{*}{6} & \multirow{2}{*}{$\begin{array}{l}\text { N 06 } 40958^{\prime} \\
\text { E } 002^{\circ} 00950^{\prime}\end{array}$} & GC1 & 0.25 & \multirow{2}{*}{$\begin{array}{l}\text { N 07 } 04936^{\prime} \\
\text { E } 002^{\circ} 06294^{\prime}\end{array}$} & ZTII1 & 3.05 & \multirow{2}{*}{$\begin{array}{l}\text { N 06 }{ }^{\circ} 57515^{\prime} \\
\text { E } 002^{\circ} 15245^{\prime}\end{array}$} & MC1 & 0.42 \\
\hline & & GC2 & 5 & & ZTII2 & 6 & & MC2 & 5 \\
\hline \multirow{2}{*}{7} & \multirow{2}{*}{$\begin{array}{l}\text { N } 06^{\circ} 40988^{\prime} \\
\text { E } 002^{\circ} 01051^{\prime}\end{array}$} & GS1 & 0.20 & & & & \multirow{2}{*}{$\begin{array}{l}\text { N } 06^{\circ} 57464^{\prime} \\
\text { E } 002^{\circ} 15280^{\prime}\end{array}$} & MS1 & 0.4 \\
\hline & & GS2 & 5 & & & & & MS2 & 5 \\
\hline \multirow[b]{2}{*}{8} & N 064 40958' & GNE1 & 0.20 & & & & N 0657602' & MNE1 & 0.05 \\
\hline & E $002^{\circ} 00950^{\prime}$ & GNE2 & 5 & & & & E $002^{\circ} 15107^{\prime}$ & MNE2 & 5 \\
\hline 9 & & & & & & & N 0657556' & ME1 & 0.15 \\
\hline & & & & & & & E $002^{\circ} 15289^{\prime}$ & ME2 & 4.5 \\
\hline 10 & & & & & & & N $06^{\circ} 58747^{\prime}$ & MT1 & 4 \\
\hline 10 & & & & & & & E $002^{\circ} 13817^{\prime}$ & MT2 & 7 \\
\hline
\end{tabular}

\section{Results and Discussion}

\subsection{Estimate of Quantitive Composition of Clayey Minerals}

This quantification is based on the evaluation of surfaces of the peaks, of the harmonic reflections (001), of argil laceous minerals on the diffractogram of the treatment ethylene glycol. They are the peaks with 17.10 and $7 \AA$ respectively of the smectite, the illite and kaolinite. Surfaces obtained are brought back to a total of 100\% [11]. The use of the diffractogram of the treatment glycol is justified by the fact that, our samples not comprising a chlorite, there is no overlap compared to the reflections of argillaceous minerals. Moreover, the estimate based on the surface of the peaks makes it possible to minimize the errors caused by the variation of the crystallinity of the samples. Indeed a low crystallinity would cause changes in the intensity of the peaks, but not of their surface [12]. The approximate mineralogical compositions of some of these samples were determined and are deferred in Table 2.

One can conclude that GN and MN contain on average, more smectite (respectively 82.46\%, 92.22\%) than kaolinite (respectively $15.77 \%$ and $7 \%$ ) contrary to ZN (28.40\% of smectite, $70.93 \%$ of kaolinite) Figure 3 and Table 2. These fine fractions are enough good quality because a good part of quartz was eliminated by sedimentation Figure 3, Figure 4.

\subsection{Determination of the Nature of the Smectites: The Test of Hoffmann Then of Grenne-Kelly}

For our samples the rate of iron (Table 3), on average of $7.5 \%$ allows to move aside the nontronite whose minimal content of ironis of 15\% [7]. The test of Hoffmann [13] then of Grenne-Kelly [14] (saturation with Li, 
Table 2. Quantitative composition of the argillaceous minerals of fraction $<2 \mu \mathrm{m}$.

\begin{tabular}{|c|c|c|c|c|}
\hline $\begin{array}{l}\text { Samples Saturated } \\
\text { with Glycol }\end{array}$ & \% Smectite & \% Kaolinite & \% Illite & \% Quartz \\
\hline GC1G & 89.13 & 9.84 & Traces & 1.03 \\
\hline GC2G & 84.76 & 14.17 & ‘' & 1.07 \\
\hline GNEIG & 76,74 & 20.48 & “ & 2.27 \\
\hline GNIG & 77.30 & 20.07 & “ & 2.63 \\
\hline GSO1G & 84.37 & 15.01 & “ & 0.62 \\
\hline GSO2G & 82.47 & 15.02 & “ & 2.51 \\
\hline Average GN & 82.46 & 15.77 & Traces & 1.69 \\
\hline ME1G & 82.01 & 17.70 & & 0.29 \\
\hline MNIG & 92.31 & 7.23 & & 0.46 \\
\hline MNOIG & 97.32 & 2.26 & & 0.42 \\
\hline MO2G & 98.74 & 0.87 & & 0.39 \\
\hline MSG & 90.72 & 6.94 & & 2.34 \\
\hline Average MN & 92.22 & 7 & & 0.78 \\
\hline ZPI1 G & 29.83 & 69.78 & Traces & 0.39 \\
\hline ZPI2G & 28.86 & 70.84 & “ & 0.30 \\
\hline ZPII1G & 10.65 & 87.33 & “ & 2.022 \\
\hline ZPOG & 32.09 & 67.47 & “ & 0.44 \\
\hline ZTI2G & 29.93 & 69.64 & “ & 0.43 \\
\hline ZTII1G & 39.06 & 60.53 & “ & 0.41 \\
\hline Average ZN & 28.40 & 70.93 & Traces & 0.67 \\
\hline
\end{tabular}

Table 3. Elementary chemical composition of the samples of Zogbodomey, of Gbedji-Kotovi and of Sehoue-Massi

\begin{tabular}{ccccccc}
\hline $\begin{array}{c}\text { Samples } \\
\text { Elements }\end{array}$ & MNO1 & MNO1N & GNE1 & GNE1N & ZTI2 & ZTI2N \\
\hline $\mathbf{S i O}_{2}$ & 54.84 & 47.5 & 45.58 & 44.8 & 52.67 & 43.53 \\
$\mathbf{A l}_{2} \mathbf{O}_{3}$ & 16.75 & 22.02 & 21.13 & 21.58 & 21.07 & 28.88 \\
$\mathbf{F e}_{2} \mathbf{O}_{3}$ & 7.11 & 8.49 & 9.61 & 8.18 & 11.25 & 7.34 \\
$\mathbf{M g O}$ & 1.51 & 1.91 & 1.72 & 1.8 & 0.45 & 1.46 \\
$\mathbf{C a O}$ & 1.1 & 1.25 & 0.87 & 0.88 & 0.3 & 0.48 \\
$\mathbf{N a} \mathbf{O}_{2} \mathbf{O}$ & 0.01 & 0.062 & 0.2 & 0.12 & 0.06 & 0.09 \\
$\mathbf{K}_{\mathbf{2}} \mathbf{O}$ & 0.01 & 0.09 & 0.48 & 0.65 & 0.27 & 0.44 \\
$\mathbf{T i O} \mathbf{O}_{2}$ & 1.09 & 1.15 & 1.34 & 1.22 & 1.46 & 1.34 \\
$\mathbf{P}_{2} \mathbf{O}_{5}$ & 0.07 & 0.08 & 0.06 & 0.05 & 0.05 & 0.10 \\
$\mathbf{L O I}$ & 17.12 & 18.03 & 19.36 & 20.8 & 12.44 & 15.96 \\
$\mathbf{T O T A L}$ & 99.61 & 100.58 & 100.35 & 100.08 & 100.02 & 99.62 \\
\hline
\end{tabular}


Counts

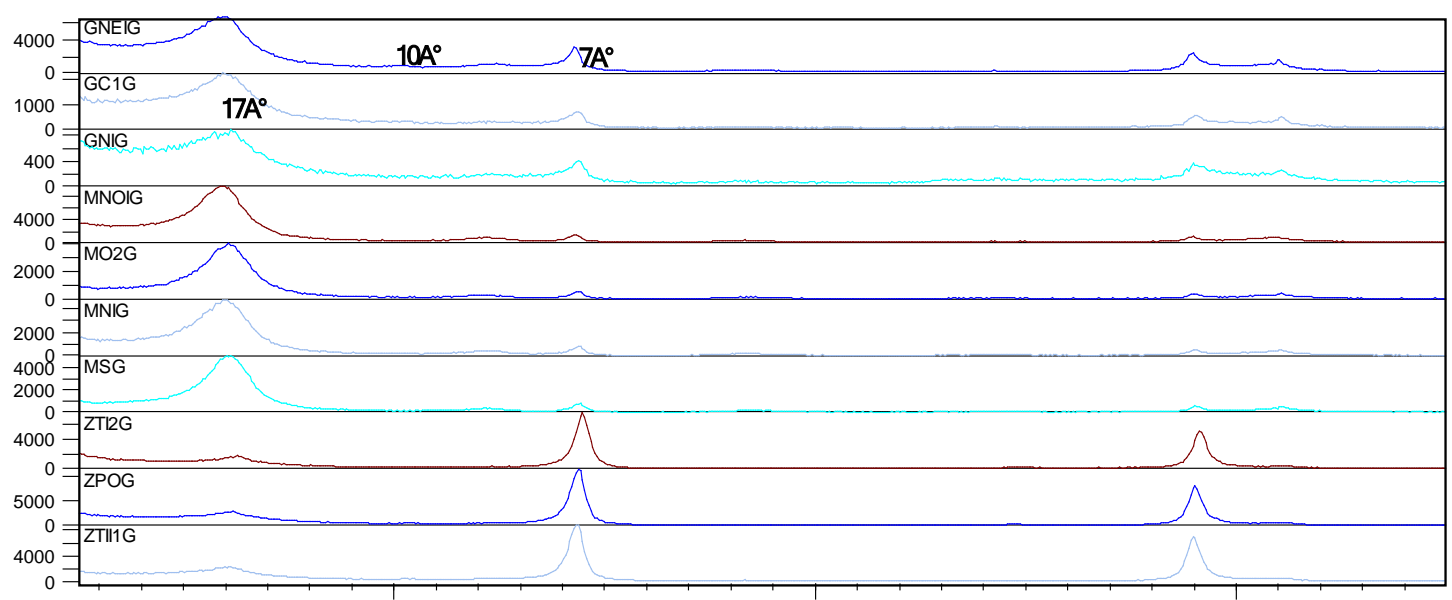

Figure 3. The diffractogram of the treatment ethylene glycol.

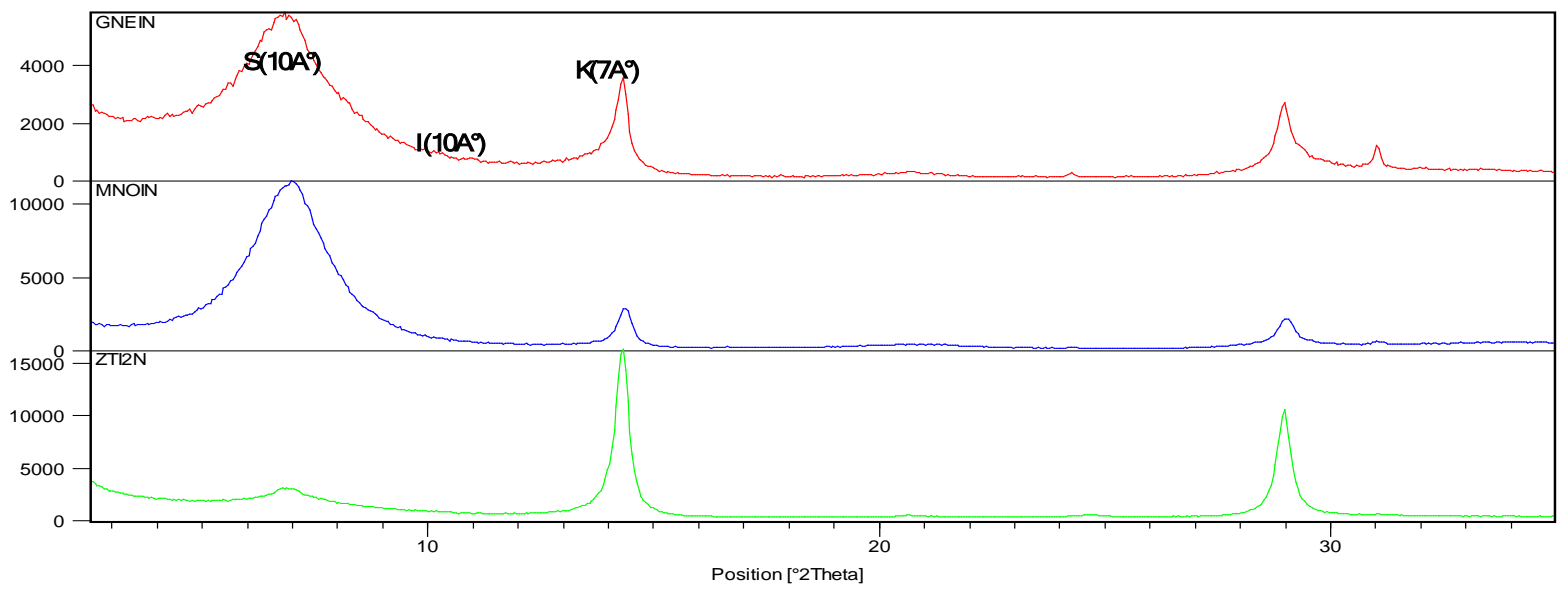

Figure 4. Diffractograms of fine (normal) fractions.

heating at $250^{\circ} \mathrm{C}$ one night, then saturation with ethylene glycol) allows to differentiate in the dioctaedric smectites, montmorillonites of the beidellites. Smectite take place then between 12 and $13 \AA$. Then, one heats at approximately $300^{\circ} \mathrm{C}$ during one night the saturated smectite. Lithium migrates in octahedral position, thus cancelling the octahedral charges. Afterwards exchange of $\mathrm{Li}$ and heating, the oriented preparations of the smectites give to the X-ray a peak between 9 and $10 \AA$. After having added glycol, the beidellites which have moreover a tetrahedral charge will pass to $17 \AA$ because they can still fix ethylene glycol molecules. On the other hand montmorillonites which do not have any more octahedral charges and not having tetrahedral charges initially, cannot fix any ethylene glycol and will remain between 9 and $10 \AA$ [15]. Practically the difficulty consists in exchanging the smectites with lithium. Lithium takes with difficulty the place of the other ions in interfoliaceous position and if little lithium penetrates in the smectite then, the octahedral charges all are not neutralized. Thus the test loses all its significance. To be certain that the exchange was well made, it is necessary in each series, to treat a montmorillonite standard at the same time, as witness [16]. The diffractograms obtained for this purpose are regrouped on Figures 5-8.

On Figure 5, normal montmorillonite (reference MTMN) is to $12.62 \AA$. Saturated with lithium, it (MTMLN) passes to $12.40 \AA$. Then heated, it (MTMLC) is reduced to $9.8 \AA$, value that montmorillonite keeps even after addition glycol thereafter (MTMLCG) On Figure 6 the smectite of GNEI of the normal fraction (GNEIN) is at $15 \AA$. Saturated with lithium (GNEILN), it is at $12.40 \AA$, then heated (GNEILC) it passes to 10 to find $17 \AA$ after addition glycol (GNEILCG). GNEILCG contrary to the montmorillonite remains with $9.80 \AA$. One concludes from it that the smectite of Gbedji-Kotovi is well a beidellite. By considering the diffractograms contained in Figure 7 and Figure 8 relating to sample MNO1 of Sehoue-Massi and sample ZTII2 of Zogbodomey, 


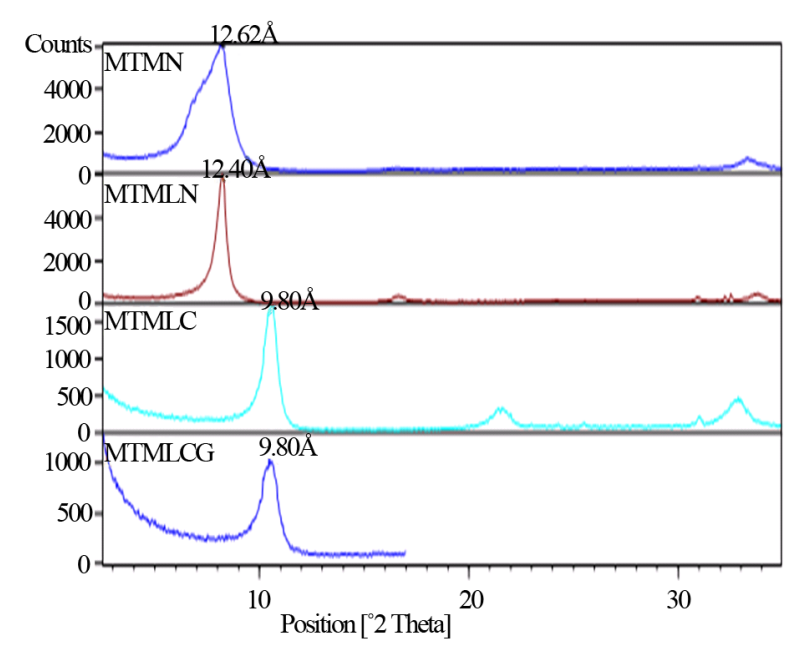

Figure 5. Diffractograms of clayey fractions treated of montmorillonite reference.

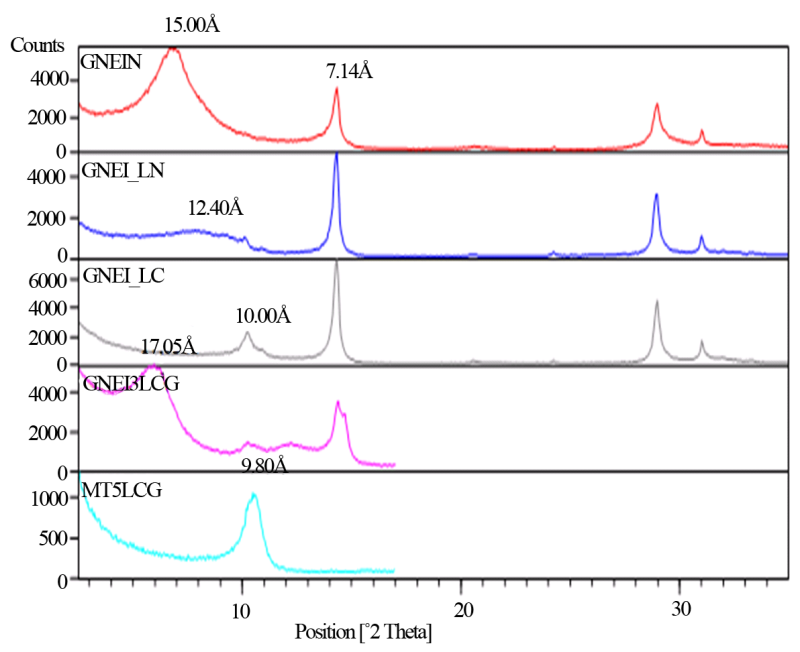

Figure 6. Diffractograms of treated samples GNE1.

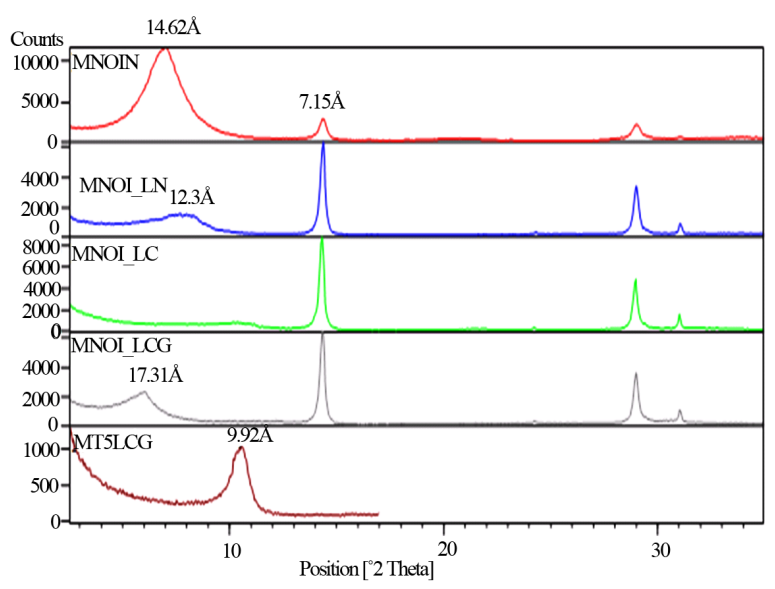

Figure 7. Diffractograms of treated samples MNO1. 


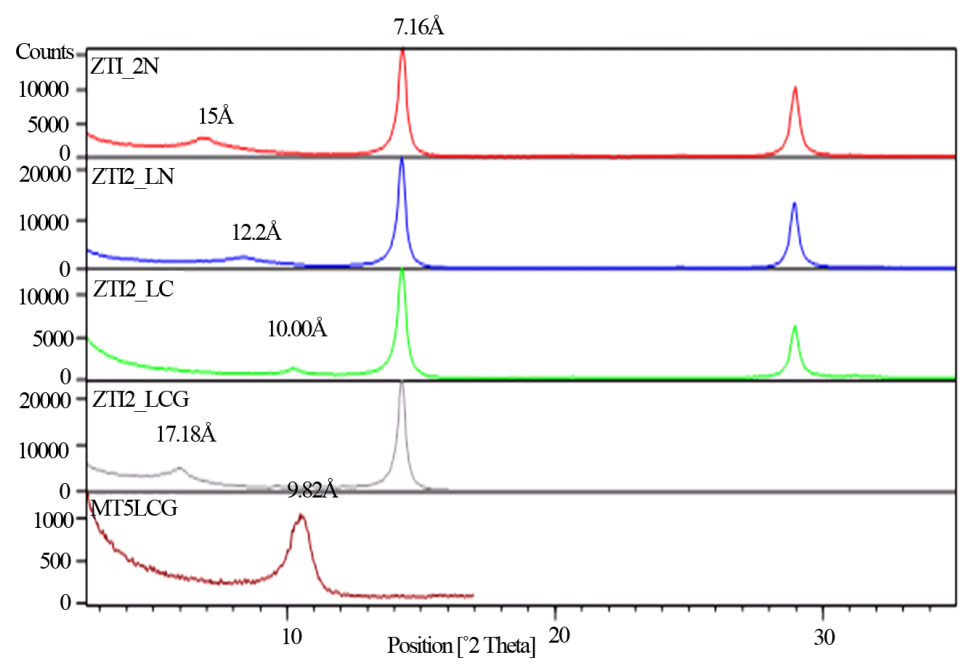

Figure 8. Diffractogramsof treated samples ZTI2.

one thus leads to the same observations with the same conclusion with knowing that the smectites of the studied samples are beidellites.

\subsection{Determination of the Origin of Smectites: Test of Behaviour with the Potassium}

This determination by diffraction of X-rays, was carried out on the fine fraction (normal) and the fine fraction saturated with potassium with a representative sample of each site thus G, M and Z. The behavior of minerals 2/1 saturated with potassium bring several information on their properties [17]. It allows particularly to distinguish the smectites of transformation (resulting from the micas) of the true smectites (newly formed or neogenetic) [11], [15]. Indeed it is well-known that not very hydratable cations like $\mathrm{K}$, whose diameter corresponds approximately to This causes the contraction of mineral towards $10 \AA$ what one calls the "retrogradation of potassium", this cation becoming not easily exchangeable then and especially for the smectites of transformation. For the true smectites closing to $10 \AA$ generally does not intervene and their interfoliaceous distances are between $12 \AA$ and $15 \AA$ [11] [18]. The diffractograms obtained are recorded on Figure 9.

For GNE1, the peak at $15 \AA$ of fine fraction (GNE1N or G normal) is replaced with two peaks of the fraction saturated with potassium (G-K) at $13 \AA$ and at $10.2 \AA$ (Figure 9), corresponding respectively to the presence of a true smectite and of a smectite of transformation. This is explained by the fact that this sample is in the bed of a river which receives a bit from everything. For MNO1, the peak at $14.7 \AA$ of its fine part (MNO1N or M normal) is towards $12.7 \AA$ with (M-K) its part saturated with $\mathrm{K}$. We are in the presence of a true, neoformed smectite by the ions accumulated in the depression of the LAMA. Lastly, with its fine fraction (ZTI2N or Z normal), ZTI2 has a peak towards $15 \AA$ which moves at $10 \AA$ while becoming Z-K ( saturated with potassium) because of closing due to the saturation with $\mathrm{K}$ (Figure 9). Indeed its smectite is of transformation resulting from the mica probably coming from deterioration from the granite, because ZTI2 come from Zogbodomey which is beside of the base granito-migmatic.

\subsection{Elementary Chemical Analysis}

The chemical analysis gave the results gathered in Table 3 and Table 4. Quantitatively the samples contain all mainly the oxides $\mathrm{SiO}_{2}(43.5 \%-54.8 \%)$ and $\mathrm{Al}_{2} \mathrm{O}_{3}(16.7 \%-28.9 \%)$. Follow-up in the minority of $\mathrm{Fe}_{2} \mathrm{O}_{3}$ or and $\mathrm{FeO}(7.1 \%-11.2 \%)$, and of $\mathrm{TiO}_{2}(1.09 \%-1.5 \%)$ and according to each site of $\mathrm{Na}_{2} \mathrm{O}, \mathrm{P}_{2} \mathrm{O}_{5}$ of $\mathrm{MgO}$ of $\mathrm{CaO}$ and $\mathrm{K}_{2} \mathrm{O}$ in variable quantity. The chemical analyses correctly translate the results of the analysis by diffraction of the X-ray. They show indeed that the samples contain all, a content of $\left(\mathrm{SiO}_{2}+\mathrm{Al}_{2} \mathrm{O}_{3}\right)$ ranging between 66.4 and 71.6. They are thus essentially silico-aluminous minerals with prevalence of $\mathrm{SiO}_{2}$.

The relationship $\alpha=\mathrm{SiO}_{2} / \mathrm{Al}_{2} \mathrm{O}_{3}$ about total fraction, variable between 2.2 and 3.3 (Table 4) is quite characteristic of argillaceous minerals. These values largely higher than 1.1, that of standard kaolinite [19] confirm the presence of free silica (quartz, amorphous silica...) and other argillaceous minerals detected with the X-ray. 


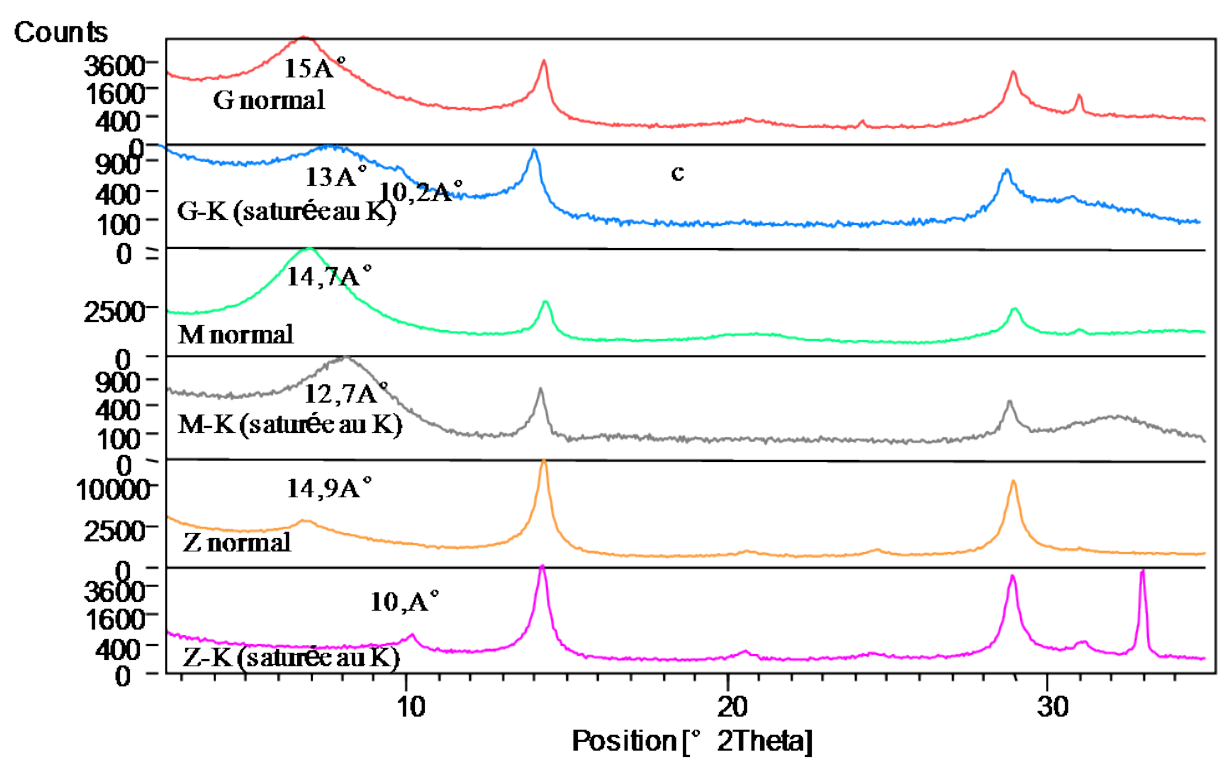

Figure 9. Diffractograms of fine (normal) fractions and fractions saturated with the potassium.

Table 4. Rapports $\alpha$ and of $\beta$ for samples of Zogbodomey, Gbédji-Kotovi and Sehoue-Massi.

\begin{tabular}{ccccccc}
\hline $\begin{array}{c}\text { Samples } \\
\text { Rapports } \boldsymbol{\alpha} \text { and } \boldsymbol{\beta}\end{array}$ & MNO1 & MNO1N & GNE1 & GNE1N & ZTI2 & ZTI2N \\
\hline $\boldsymbol{\alpha}=\mathrm{SiO}_{2} / \mathrm{Al}_{2} \mathbf{O}_{3}$ & 3,3 & & 2,2 & & 2,5 & \\
$\begin{array}{c}\boldsymbol{\beta}=\mathrm{SiO}_{2} / \\
\left(\mathbf{A l}_{2} \mathbf{O}_{3}+\mathbf{F e}_{2} \mathbf{O}_{3}\right)\end{array}$ & & 1,6 & & 1,5 & & 1,2 \\
\hline
\end{tabular}

The rapport $\beta=\mathrm{SiO}_{2} /\left(\mathrm{Al}_{2} \mathrm{O}_{3}+\mathrm{Fe}_{2} \mathrm{O}_{3}\right)$ concerning the fine fraction and varying between 1.6 for MNOIN and 1.2 for ZTI2N (Table 4), indicates the presence of clays of the type $2 / 1$ the more so as this value would be close to 2 [20]. Indeed GNE1N, MNO1N and ZTI2N respectively contain 82\%, 92\% and 28\% of smectite (Table 2)

All the samples also contain, of small quantities of $\mathrm{TiO}_{2}$ indicating the presence on average of $1.27 \%$ of anatase also detected with the diffraction of x-rays. Moreover, only the materials of GNE1contain an appreciable average quantity of $\left(\mathrm{K}_{2} \mathrm{O}+\mathrm{Na}_{2} \mathrm{O}\right)$ equalizes at $1.5 \%$, suggesting the presence of feldspar detectable also by the diffraction of x-rays. The Percentage of $\mathrm{Fe}_{2} \mathrm{O}_{3}$ suggests the presence of goethite found in ZTI2 or structural iron in the smectites of the 3 sites. This will be also confirmed by Spectrométry Mössbauer.

\subsection{Physico-Chemical and Granulometric Analyses}

The results of granulometry are represented on Figure 10. The definition of the clay from the particle with a lower diameter than $2 \mu \mathrm{m}$ must be reservedly taken. Indeed, some clayey particles have the upper size than $2 \mu \mathrm{m}$ while some particles of minerals linked to clay (feldspar, quartz, goethite, etc.) have a lower size than $2 \mu \mathrm{m}$. It is why ones think that the clayey minerals begin being present from fine silts [8] and that in lower fraction than 2 $\mu \mathrm{m}$ can be traces of associate minerals. The particles of these samples are divided into four great classes as shown it on Figure 8. Clays (diameter $<2 \mu \mathrm{m}$ ) are in a decreasing way, 48.9; 31.4\% and 23.4\% respectively for the samples $\mathrm{G}, \mathrm{M}$ and $\mathrm{Z}$. The fine silts $(2-20 \mu \mathrm{m})$ are more numerous in $\mathrm{M}(64.8 \%)$, than $\mathrm{G}(48.2 \%)$ and $\mathrm{Z}$ (39\%). The coarse silts (20 - $50 \mu \mathrm{m})$ are more significant in Z (22.9\%), than $\mathrm{M}(3.2 \%)$ and G (1.9\%). Fine sands (50 - $200 \mu \mathrm{m}$ ) are in an increasing way 1; $0.7 \%$ and $14.6 \%$ respectively for samples $\mathrm{G}, \mathrm{M}$ and $\mathrm{Z}$. The three samples are primarily silty-argillaceous (more than $62 \%$ clay + silt) with more clay for G (48.9\%), more fine silt for $\mathrm{M}(64.8 \%)$ and a texture balanced enough for ZY with a little bit of every element.

The results of the physico-chemical analysis (Table 5) come to confirm those of the mineralogical analysis. It is noticed whereas clays of the three sites have capacities of cationic exchange lower than those their majority clay components. $40.9 \mathrm{meq} / 100 \mathrm{~g}$ for the $\mathrm{G}, 39.8 \mathrm{meq} / 100 \mathrm{~g}$ for $\mathrm{M}$ and $4.17 \mathrm{meq} / 100 \mathrm{~g}$ for the $\mathrm{Z}$ against 80 $150 \mathrm{meq} / 100 \mathrm{~g}$ for the smectites and 5 - $15 \mathrm{meq} / 100 \mathrm{~g}$ for kaolinites [21]. These low values would be explained 


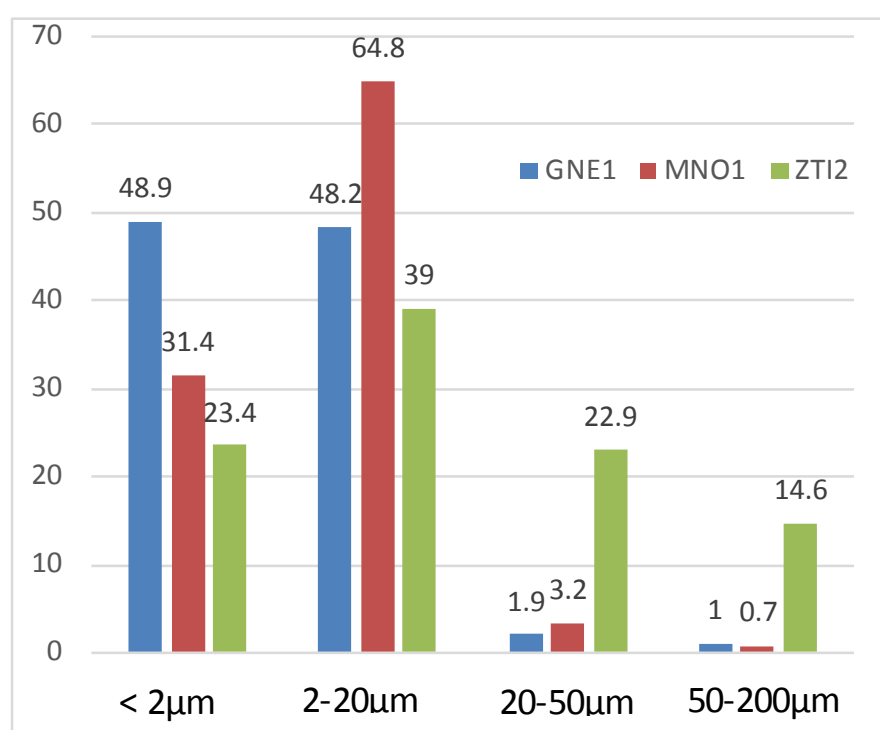

Figure 10. Granulométric composition of GNE1, MNO1 and ZTI2.

Table 5. Cationic Exchange Capacity (CEC), specific surface and density GNE1, MNO1 and ZTI2.

\begin{tabular}{cccc}
\hline Samples & CEC in meq/100 g & Density & Specific Surface $\left(\mathrm{m}^{2} / \mathrm{g}\right)$ \\
\hline GNE1 & 40,9 & 2,36 & 105,41 \\
MNO1 & 39,8 & 2,33 & 100,59 \\
ZTI2 & 3,8 & 2,66 & 69,2 \\
\hline
\end{tabular}

by the fact that in the method used measurements are done on the total fractions which contains in our case a considerable quantity of quartz unable to exchange cations. Moreover, kaolinites are not very exchanger of cations what explain the low value $3.8 \mathrm{meq} / 100 \mathrm{~g}$ of $\mathrm{Z}$ which contains more kaolinite than $\mathrm{G}$ and $\mathrm{M}$. The density gives an idea of the prevalent species in samples. Thus the samples $\mathrm{G}($ density $=2.36)$ and $M$ (density $=2.37)$ are smectitic $(2.08-2.35)$ whereas the density of Z (2.64) are kaolinitic (density $=2.40-2.64)$ and/or quartz (density $=2.65$ ). It is noticed that moreover GNE1 and MNO1, which are smectitic than ZTI2, have a greater specific surface (100.59 meq/100 g against $69.2 \mathrm{~m}^{2} / \mathrm{g}$ for ZTI2 ) and ZTI2 which contains more kaolinite, a little smectite and a little goethite which has raised more this by rapport of the specific surface of kaolinite (10 - 30 $\left.\mathrm{m}^{2} / \mathrm{g}\right)[22]$.

\subsection{Study Carried out by Infrared and Mössbauer Spectroscopies}

For IR, the analysis of samples GNEIN, MNOIN and ZTI2N are going in field from $50 \mathrm{~cm}^{-1}$ to $400 \mathrm{~cm}^{-1}$ and $400 \mathrm{~cm}^{-1}$ to $4000 \mathrm{~cm}^{-1}$. The spectra obtained are represented on Figure 11(a) and Figure 11(b). On Figure 11(a) are observed:

- 3 bands due to the vibrations of isosceles triangle $\mathrm{H}-\mathrm{O}-\mathrm{H}$ of symmetry C2v [23] which are roughly to 277. $\mathrm{cm}^{-1}$ (symmetrical elongation), to $244 \mathrm{~cm}^{-1}$ (asymmetrical elongation) and to $199 \mathrm{~cm}^{-1}$ (symmetrical deformation).

- The beginning of a series of bands around $346 \mathrm{~cm}^{-1}$ which characterizes the $\mathrm{SiO}_{4}$ tetrahedron. This series continues on the Figure 11(b) by the bands with $427 \mathrm{~cm}^{-1}$ and $467 \mathrm{~cm}^{-1}$ approximately previously notified.

Figure 11(b) in particular makes it possible to highlight the following differences:

- Around $623 \mathrm{~cm}^{-1}$ is a band hardly visible on the spectrum of GNEIN but non-existent on ZTI2N which would correspond to the elongation $\mathrm{Al}-\mathrm{O}$ of a smectite [24].

- The three bands with $691 \mathrm{~cm}^{-1}, 743 \mathrm{~cm}^{-1}$ and $777 \mathrm{~cm}^{-1}$ approximately visible on the three spectra are characteristic of a kaolinite [25] [26]. If the two last bands are equal intensities, kaolinite is then of a good crystal 


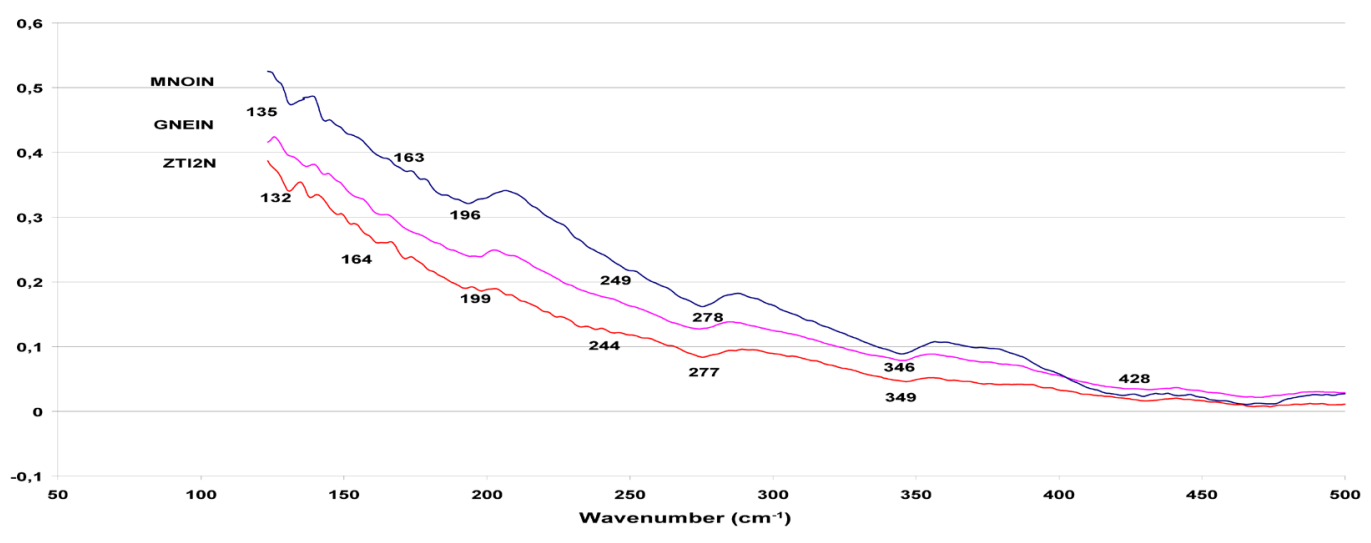

(a)

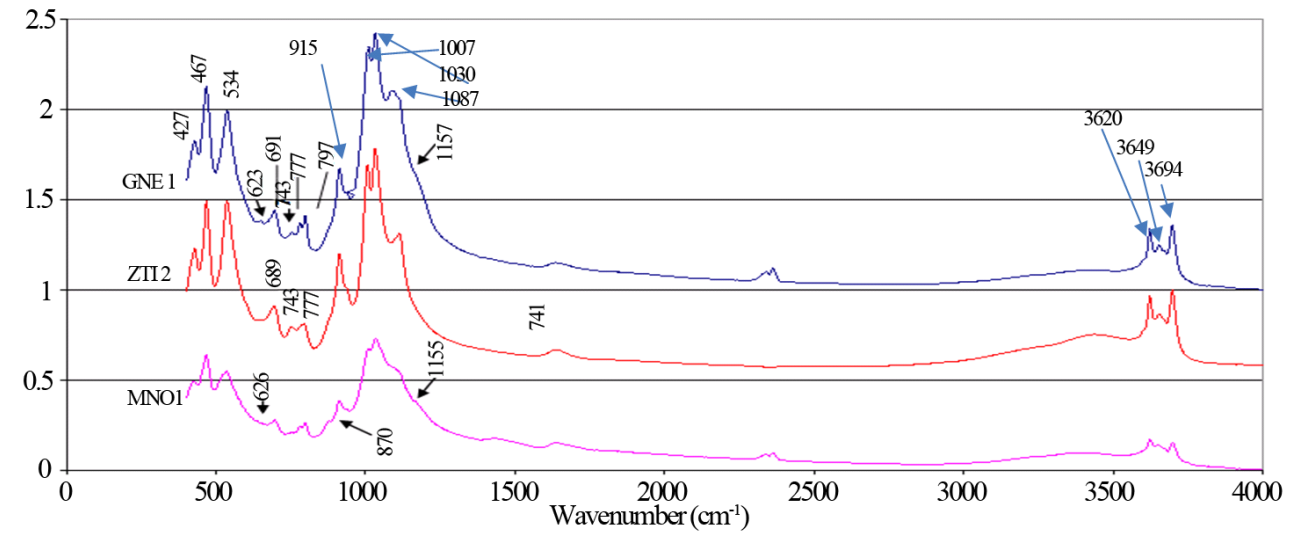

(b)

Figure 11. (a) Infra-red spectrum of GNE1N, MNO1N and ZTI2N between $50 \mathrm{~cm}^{-1}$ and $450 \mathrm{~cm}^{-1}$; (b) Infra-red spectrum of GNE1N, MNO1N and ZTI2N between $400 \mathrm{~cm}^{-1}$ and $4000 \mathrm{~cm}^{-1}$.

linity [27]. It is the case of ZTI2N which is kaolinitique besides than the two others.

- Moreover GNEIN and MNOIN present three other bands towards $797 \mathrm{~cm}^{-1}, 871 \mathrm{~cm}^{-1}$ and $1155 \mathrm{~cm}^{-1}$. The two first are characteristic of the deformation of $\mathrm{O}-\mathrm{H}$ surrounded by two ions of $\mathrm{Fe}^{3+}$ or $\mathrm{Al}^{3+}$ and $\mathrm{Fe}^{3+}$ following substitution of aluminum of a smectite by iron. The last band (shoulder) could be allotted to the elongation of Si-O-Si of a smectite.

We notice a resolved $\mathrm{OH}$ deformation band at $915 \mathrm{~cm}^{-1}$ for Al-OH in beidellite, and 3 bands with positions of about $1007 \mathrm{~cm}^{-1}, 1030 \mathrm{~cm}^{-1}$ and $1087 \mathrm{~cm}^{-1}$ which can be allotted to the vibrations of valence of the Si-O.

Finally between $3500 \mathrm{~cm}^{-1}$ to $3800 \mathrm{~cm}^{-1}$, it is necessary notably to signalize the presence of the vibrations of valence of groupings $\mathrm{OH}$ related to the aluminum atoms which result in 4 following absorption bands:

- 1 band solved enough around $3620 \mathrm{~cm}^{-1}$ for the internal $\mathrm{OH}$ [28] as well in the minerals 1:1 that in the 2:1.

- a $2^{\text {nd }}$ band with approximately $3650 \mathrm{~cm}^{-1}$, sometimes a 3rd towards $3660 \mathrm{~cm}^{-1}$ and a $4^{\text {th }}$ also enough solved to approximately $3695 \mathrm{~cm}^{-1}$, for the external $\mathrm{OH}$ [29], [30]. this only in the minerals 1:1.

These fine fractions contain primarily kaolinite and smectite thus confirming the analyses with the X-ray.

For Mössbauer, the study is made at the room temperature. The results are represented on Figure 12 and are consigned in Table 6.

For GNE1 magnetic 1, pas de spectrum. One observes a doublet allotted to $100 \%$ of Fe III in an octahedral environment more or less distorted with an isomeric displacement $\delta 1=0.36 \mathrm{~m} / \mathrm{s}$, a quadripolar bursting $\Delta 1=$ $0.54 \mathrm{~m} / \mathrm{s}$, and a width of line at middle height $\Gamma=0.55 \mathrm{~m} / \mathrm{s}$. This iron can be structural iron in substitution for the aluminum in clay or of super paramagnetic iron impurity [23], [31].

For MNO1, there is either magnetic spectrum; simulation gives two characteristic doublets:

- A doublet, very broad ( $\delta 1=0.34 \mathrm{~m} / \mathrm{s}, \Delta 1=0.53 \mathrm{~m} / \mathrm{s}$ and $\Gamma=0.34 \mathrm{~mm} / \mathrm{s}$ ), corresponds to Fe III in octahedral site with 94\% There too one can allot it either to iron substituted for aluminum in the structure of silico- 

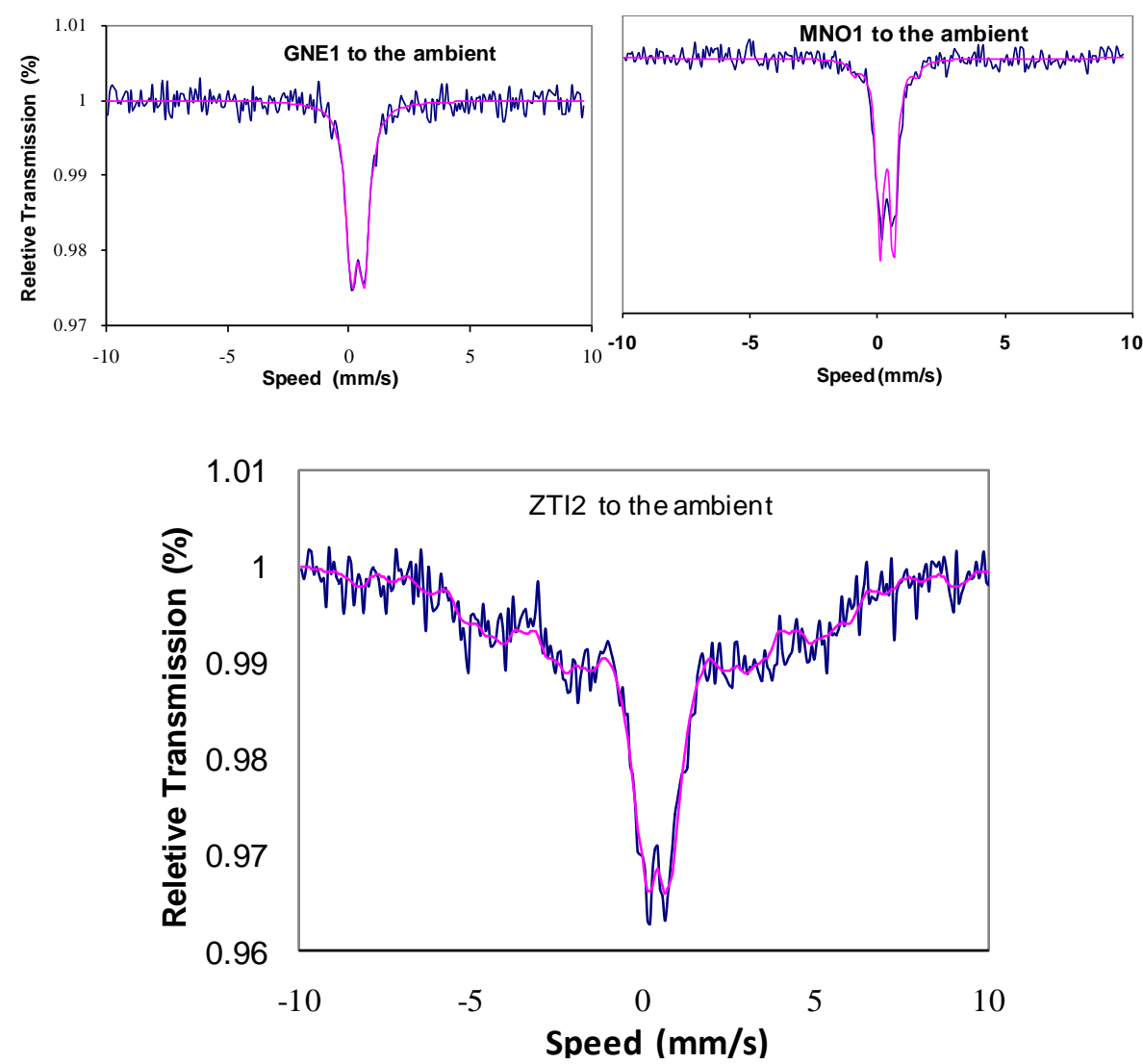

Figure 12. Mossbauer spectra of the three samples at the ambient temperature.

Table 6. Fe Mössbauer data relating to the studied samples (at ambient temperature).

\begin{tabular}{ccccccl}
\hline Samples & $\delta(\mathrm{mm} / \mathrm{s})$ & $\Delta(\mathrm{mm} / \mathrm{s})$ & $\Gamma_{(\mathrm{mm} / \mathrm{s})}$ & $\mathrm{H}(\mathrm{T})$ & Contr. $(\%)$ & Attribution \\
\hline \multirow{2}{*}{ GNE1 } & 0.36 & 0.54 & 0.55 & - & 100 & $\mathrm{Fe}^{\text {III }}$ octahedral \\
& 0.34 & 0.53 & 0.34 & - & 94 & $\mathrm{Fe}^{\text {III }}$ octahedral \\
& 0.29 & 2.46 & 0.34 & - & 6 & $\mathrm{Fe}^{\text {III }}$ tetrahedral \\
& 0.37 & 0.52 & 0.49 & - & 36.4 & $\mathrm{Fe}^{\text {III }}$ octahedral \\
\multirow{2}{*}{ ZTI2 } & 0.54 & 1.53 & 0.49 & - & 8.3 & $\mathrm{Fe}^{\text {III }}$ octahedral \\
& 0.40 & - & 0.75 & 29.5 & 24.9 & \\
& 0.53 & - & 0.75 & 19.2 & 19.2 & \\
& 0.92 & - & 0.75 & 13.7 & 11.2 & \\
\hline
\end{tabular}

( $\delta$ = someric displacement compared to $\alpha \mathrm{Fe} ; \Delta=$ quadripolar bursting; $\Gamma=$ width of line at middle height; $\mathrm{H}=$ hyperfine magnetic field).

aluminous or for iron super paramagnetic impurity.

- The other, of small surface represents tetrahedral Fe III ( $\delta 2=0.29 \mathrm{~m} / \mathrm{s}, \Delta 2=2.46 \mathrm{~m} / \mathrm{s}, \Gamma=0.34 \mathrm{~m} / \mathrm{s})$ for $6 \%$ of the total iron. This could agree with structural iron which replaced silicon in a tetrahedral environment relating to the presence of the beidellite in the sample as the $\mathrm{X}$-ray indicates it.

Finally ZTI2 has a spectrum with different sites:

- Two no magnetic contributions which form the central envelope with $40 \%$ on average. Contributions, which can be allotted to FeIII in octahedral site.

- And three magnetic contributions which give the envelope widened in the spectrum and correspond to ap- 
proximately $60 \%$. This with $\mathrm{H}<$ with $50 \mathrm{~T}$, signalize the presence of the goethite detected to $\mathrm{x}$-rays, [23] [32].

On the whole, it is deduced that the beidellite of GNE1 contains $\mathrm{Al}^{3+}$ and $\mathrm{Si}^{4+}$ in its tetrahedron and that of MNO1 contains in addition, $\mathrm{Fe}^{3+}$.

\subsection{Determination of Chemical Formula of Samples GNE1N and MNO1N}

For that, we regarded GNE1N and MNO1N as smectites considering the strong proportion of smectite contained in these samples (respectively $82.46 \%, 92.22 \%$ ) and we used the method of M. ÖNAL [33] supported in particular of the results of Mössbauer. What gives:

GNO1N: $\left.\mathrm{Na}_{0,02}^{+} \mathrm{K}_{0,06}^{+} \mathrm{Ca}^{2+}{ }_{0,07} \mathrm{Mg}^{2+}{ }_{0,16}\left[\left(\mathrm{Al}^{3+}, \mathrm{Fe}^{3+}\right)_{1,95} \mathrm{Mg}^{2+}{ }_{0,05}\right)\right]\left[\mathrm{Si}^{4+}{ }_{3,49} \mathrm{Al}^{3+}{ }_{0,51}\right] \mathrm{O}_{10,00}(\mathrm{OH})_{2,00} \mathrm{H}_{2} \mathrm{O}_{\mathrm{n}}$. MNO1N: $\left.\mathrm{Na}_{0,01}^{+} \mathrm{K}_{0,01}^{+} \mathrm{Ca}^{2+}{ }_{0,10} \mathrm{Mg}^{2+}{ }_{0,15}\left[\left(\mathrm{Al}^{3+}, \mathrm{Fe}^{3+}\right)_{1,94} \mathrm{Mg}^{2+}{ }_{0,06}\right)\right]\left[\mathrm{Si}^{4+}{ }_{3,53}\left(\mathrm{Al}^{3+}, \mathrm{Fe}^{3+}\right)_{0,47}\right] \mathrm{O}_{10,00}(\mathrm{OH})_{2,00} \mathrm{H}_{2} \mathrm{O}_{\mathrm{n}}$.

\section{Conclusion}

Globally, the three samples are essentially silty-argillaceous (more than $62 \%$ clay + silt) with $48.9 \%$ of clay for GNE1, 31.4\% of clay for MNO1 and 23.4\% of clay for ZTI2. The principal minerals highlighted in the clayey fraction lower than $2 \mu \mathrm{m}$ are the beidellite and kaolinite. GNE1N and MNO1N are practically beillidelitic (more than $82 \%$ of beillidelite) and ZTI2N practically kaolinitic (70\% of kaolinite). Consequently, GNE1 and MNO1 have largest specific surfaces and capacities of exchange of cation relatively to ZTI2 (respectively $105.4 \mathrm{~m} / \mathrm{g}$; $100.6 \mathrm{~m}^{2} / \mathrm{g} ; 69.2 \mathrm{~m} / \mathrm{g}$; and $40.9 \mathrm{meq} / 100 \mathrm{~g} ; 39.8 \mathrm{meq} / 100 \mathrm{~g} ; 3.8 \mathrm{meq} / 100 \mathrm{~g}$. It comes out from these analyses that the clay of Gbedji-Kotovi and of Sèhouè-Massi will induce an enteric methane reduction more than clay of Zogbodomey. This study will be followed in further investigations by the use of clay as an additive food in Djallonké sheep.

\section{References}

[1] Chenoweth, D.P. (1996) Environmental Impact of Methanogenesis. Environmental Monitoring and Assessment, 42, 318. http://dx.doi.org/10.1007/BF00394039

[2] Ouachem, D., Soltane, M. and Kalli, A. (2008) Les pailles de céréales: Profil des fermentations et production de méthane. Sciences \& Technologie, 27, 23-28.

[3] Iheta, B., Kirov, M., Tsawlassou, G. and Houessou, A. (1983) Rapport sur les recherchesgéologiquesd' argilesdans lazone du bassincôtier: SecteurGbédji-Kotovi, Massi, Zogbodomè.

[4] Agbahoungbata, M.Y. (2012) Caractérisation et valorisation de quelquesargiles du Bénin: Application à l’adsorption du cuivredansl'eau. Mémoire de DEA. Universitéd’ Abomey-Calavi.

[5] Slansky, M. (1962) Contribution à l'étudegéologique du bassinsédimentairecôtier du Dahomeyet du Togo

[6] IRB (1989) Etude de la cartographieengéologiqueet prospection de reconnaissance au Sud du $9{ }^{\text {ème }}$ parallèle.

[7] Caillere, S. and Henin, S. (1963) Minéralogie des argiles. Masson etCie.

[8] Holtzapffef, T. (1985) Les Minérauxargileux: Préparation, analyse diffractométrique et détermination, Société Géologique du Nord, 12.

[9] Aubert, G. (1978) Méthodesd’Analyses des Sols, Centre régional de Documentation Pédagogique de Marseille (191) $2^{\text {ème }}$ trimester.

[10] Künding, W.A. (1969) Least Square Fit Program. Nuclear Instruments and Methods, 75, 336-340. http://dx.doi.org/10.1016/0029-554X(69)90624-7

[11] Satte, Y. (2010) Assemblages minéralogiques argileux et circulation thermohaline en atlantique Nord pendant les stades isotopiques 27 à 31. Thèse de doctorat de l'université du Québec à Montréal, Montréal.

[12] Tremblay, M. (1986) Etude de l’hétérogénéité du gisement de kaolin de Chateau-Richeret de son incidence sur les propriétés des mousses d’argile. Mémoire de maitriseen sciences de la terre, Université du Québec, Ville de Québec, 163 p.

[13] Hofmann, U. and Klemen, R. (1950) Verlust der Austauschfähigkeit von Lithiumionen an Bentonite durch Erhitzung. Zeitschrift für anorganische Chemie, 262, 95-99. http://dx.doi.org/10.1002/zaac.19502620114

[14] Grenne-Kelly, R. (1957) The Montmorillonite Minerals. In: Mackenzie, R.C., The Differential Thermal Investigation of Clays, Chap. V, Mineralogical Society, London, 140-164.

[15] Thorez, J. (1998) Différenciation minéralogique et génétique par DRX des smectitespost-saturées au Li et K. Applications ensédimentologie, paléopédologie, paléogéographie, paléoclimatologie, stratigraphie et enargilostratigraphiesé- 
quentielle, Vol. 30, ASF Publications, Paris, 106-107.

[16] Thiry, M. (1991) Les argilesplastiques du bassin de Paris. Groupe Français des Argiles, Livret guide, France.

[17] Robert, M. and Tessier, D. (1974) Annales Agronomiques, 26, 859.

[18] Thorez, J. (2002) Cation-Saturated Swelling Physils: An XRD Revisitation. Proceedings of the 1st Latin-American Clay Conference, Vol. 1, Funchal, Invited Lecture, Clay Geology Laboratory, Liège University, Liège, 71-85.

[19] Sorgho, B., Paré, S., Guel, B., Zerbo, L., Karfa, T. and Persson, I. (2011) Etude d'uneargile locale du Burkina Faso à des fins de décontaminationen $\mathrm{Cu}^{2+}, \mathrm{Pb}^{2+}$ et $\mathrm{Cr}^{3+}$. Journal de la Société Ouest-Africaine de Chimie, 31, 49-59.

[20] M’leyeh, A., Srasra, E. and Cheref, A. (2002) Adsorption of Heavy Metals by Natural Clays of Borj Chekir, SW of Tunis. Proceedings of International Symposium on Environmental Pollution Control and Waste Management, (EPCOWM' 2002), Tunis, 7-10 January 2002, 533-546.

[21] Morel, R. (1996) Les sols cultivés. Lavoisier, Paris.

[22] Borggaard, O.K. (1979) Selective Extraction of Amorphous Iron Oxides by EDTA from a Danish Sandy Loam. Journal of Soil Science, 30, 727-734. http://dx.doi.org/10.1111/j.1365-2389.1979.tb01022.x

[23] Sei, J. (1998) Etude de matériaux de dimensionnalitéréduite: Relation structure-propriétédans des kaolinites naturelles de Côte d’Ivoire. Thèse, Université de Montpellier, Montpellier.

[24] Kloprogge, J.T., Komarneni, S., Yanagisawa, K., Fry, R. and Frost, R.L. (1999) Infrared Emission Spectroscopic Study of the Dehydroxylation via Surface Silanol Groups of Synthetic and Natural Beidellite. Journal of Colloid and Interface Science, 212, 562-569. http://dx.doi.org/10.1006/jcis.1998.6082

[25] Russell, J.D. (1965) Infrared Study of the Reactions of Ammonia with Montmorillonite and Saponite. Transactions of the Faraday Society, 61, 2284-2294. http://dx.doi.org/10.1039/tf9656102284

[26] Farmer, V.C. (Ed.) (1974) The Infrared Spectra of Minerals. Mineralogical Society, London, 331. http://dx.doi.org/10.1180/mono-4.15

[27] Russell, J.D. and Fraser, A.R. (1994) Infrared Methods. In: Wilson, M.J., Ed., Clay Mineralogy: Spectroscopic and Chemical Determinative Methods, Chapman \& Hall, London, 11-67. http://dx.doi.org/10.1007/978-94-011-0727-3_2

[28] Velde, B. and Meunier, A. (2008) The Origin of Clay Minerals in Soils and Weathered Rocks. Springer, Heidelberg, 406 p. http://dx.doi.org/10.1007/978-3-540-75634-7

[29] Liétard, O. (1997) Contribution à l'étude des proprieties physicochimiques, cristallographiques et morphologiques des kaolins. PhD Dissertation, University of Nancy, Nancy.

[30] Njopwouo, D. (1984) Minéralogie et physic-chimie des argiles de Bomkoul et de Balengou (Cameroun). Utilisation dans la polymérisation du styrene et dans le renforcement du caoutchouc naturel. Thèse de Doctoratd'Etat, Université de Yaoundé, Yaoundé, 300 p.

[31] Soro, N.S. (2003) Influence des ions fer sur les transformations thermiques de la kaolinite. Thèse de Doctorat de l’Université de Limoges, Limoges.

[32] Goodman, B.A. and Lewis, D.G. (1981) Mössabauer Spectra of Aluminous Geothites ( $\alpha$-FeOOH). Journal of Soil Science, 32, 351-363. http://dx.doi.org/10.1111/j.1365-2389.1981.tb01711.x

[33] Önal, M. (2006) Determination of Chemical Formula of a Smectite. Department of Chemistry, Faculty of Science, Ankara University, TURKEY Series B, Vol. 52, 1-6. 